\title{
Effects of phosphorus on the growth and chlorophyll fluorescence of a Dunaliella salina strain isolated from saline soil under nitrate limitation
}

\author{
Tassnapa Wongsnansilp, ${ }^{1}$ Niran Juntawong, ${ }^{2}$ Zhe $\mathbf{W u}^{1,3}$ \\ 1 Interdisciplinary Graduate Program in Bioscience, Faculty of Science, Kasetsart University, \\ Bangkok; ${ }^{2}$ Department of Botany, Kasetsart University, Thailand; ${ }^{3}$ Institute of Genetics and \\ Physiology, Hebei Academy of Agriculture and Forestry Sciences, Plan Genetic Engineering Center \\ of Hebei Province, China
}

\begin{abstract}
An isolated Dunaliella salina (D. salina) KU XI from saline soils in northeastern Thailand was cultured in $\mathrm{f} / 2$ medium in column photobioreactor. The variations of the growth, chlorophyll and beta-carotene content and the maximum quantum yield of PS II photochemistry $\left(\mathrm{F}, / \mathrm{F}_{\mathrm{m}}\right)$ under different $\mathrm{NaH}_{2} \mathrm{PO}_{4}$ concentrations were studied. Based on the results, the growth kinetics of $D$. salina $\mathrm{KU}$ XI was established, which could simulate the algae growth rate under different phosphate concentrations and temperatures. The phosphorus could significantly affect the growth and pigments accumulations of this isolated strain. Increasing $\mathrm{NaH}_{2} \mathrm{PO}_{4}$ concentration improved the biomass, the total
\end{abstract}

Correspondence: Zhe Wu, Interdisciplinary Graduate Program in Bioscience, Faculty of Science, Kasetsart University, 50 Ngam Wong Wan Rd, Ladyaow Chatuchak, Bangkok 10900, Thailand.

Tel: +66 819381007 - Fax: +66 29405627.

Email:wuzhe26@163.com ; sucinsist@gmail.com

Acknowledgments: special thanks are due to Faculty of Fisheries, Kasetsart University for providing technique supports of Chlorophyll fluorescence; Ms. Promchup Duangmanee for her supports to finish this work.

Key words: Chlorophyll fluorescence; Dunaliella salina; Growth kinetics; Phosphorus limitation.

Contributions: TW and ZW developed the original idea and the protocol, drafted and analyzed data, wrote the manuscript; NJ provided experimental materials, equipment and manuscript correction.

Conflict of interest: the authors declare no potential conflict of interest.

Received for publication: 7 March 2016.

Revision received: 10 0ctober 2016.

Accepted for publication: 25 October 2016.

CC Copyright T. Wongsnansilp et al., 2016

Licensee PAGEPress, Italy

Journal of Biological Research 2016; 89:5866

doi:10.4081/jbr.2016.5866

This article is distributed under the terms of the Creative Commons Attribution Noncommercial License (by-nc 4.0) which permits any noncommercial use, distribution, and reproduction in any medium, provided the original author(s) and source are credited. chlorophyll and beta-carotene content, retarded the decrease of $F_{v} / F_{m}$ value. The optimal phosphate concentration for the growth of $D$. salina KU XI was above 72.6 $\mu \mathrm{M}$. The maximum biomass and beta-carotene were $0.24 \mathrm{~g} \mathrm{~L}^{-1}$ and $17.4 \mathrm{mg} \mathrm{L}^{-1}$ respectively when $\mathrm{NaH}_{2} \mathrm{PO}_{4}$ was 290.4 $\mu \mathrm{M}$. The algae growth was restrained by phosphate or nitrate when $\mathrm{NaH}_{2} \mathrm{PO}_{4}$ below $12.1 \mu \mathrm{M}$ or above $72.6 \mu \mathrm{M}$. It indicated that properly supplementing nitrate in the late growth stage with high phosphate concentration was favored for enhancing the growth and biomass production.

\section{Introduction}

Dunaliella salina (D. salina) is a type of halophilic green microalgae especially found in sea salt fields, belongs to Kingdom of Plantae, Phylum Chlorophyta, class Chlorophyceae, Family Dunaliellaceae and genus Dunaliella. ${ }^{1}$ Known for its excellent ability for accumulation of beta-carotene under stress conditions, where dry biomass can consist of up to $10 \%$ carotenoids, $40 \%$ protein and $50 \%$ lipids. ${ }^{1-3}$ Hence, $D$. sali$n a$ is widely used for producing natural beta-carotene, biofuel, biofeeds and hygienic foods. ${ }^{4}$ Large-scale commercial cultivation of $D$. salina takes place in a number of countries, including Australia, Israel, the US, and China. ${ }^{3,5,6}$ For the algal production, nitrogen and phosphorus can easily become restrained factors due to these two elements being the most likely to be present at levels insufficient for plant growth in natural environments. ${ }^{2,3,7}$

Phosphorus and nitrogen participate in various metabolic processes during algal growth and development, such as photosynthesis, pigments synthesis, cell membrane structure, signal transconduction and various enzyme activities etc. ${ }^{8-10}$ In stress conditions, such as high light intensity, low nutrition, high salinity etc. chlorophyll synthesis of D. salina is inhibited and carotenoids are synthesized. Meanwhile, the lipid accumulation was enhanced following the carotenoids synthesized. ${ }^{11,12}$ These series physiological changes improved the adaptability of $D$. salina to various adversary stress conditions. ${ }^{12,13}$ Phosphorus could significantly affect the photosynthesis rate and efficiency, regulate various physiology functions. Too high or too low phosphorus both have adverse effects on algae growth.,14

Due to the different living environments of $D$. salina strains, their optimal conditions for growth and pigments accumulation are different. ${ }^{15,16} D$. salina strain in this study was isolated from saline soils in northeastern Thailand where nearly $17 \%$ of this area is covered by saline-alkaline soil and unsuited for agricultural plantation. ${ }^{15}$ Developing algal industry in this area by using the local algae species would be a valid and economic strategy. Hence, it was very necessary to study the growth habits and growth kinetics of this strain.

Chlorophyll fluorescence is widely and successfully used as the non- 
intrusive diagnosis tool in the photosynthesis research. ${ }^{17}$ The value of $\mathrm{F} / \mathrm{F}_{\mathrm{m}}$, the maximum quantum yield of PS II photochemistry, is almost a constant for most plant/algal species under non-stressed conditions and equals to $0.832 .{ }^{18}$ For stressed and/or damaged plants, the value is markedly reduced. Thus, it is widely used to check the stressed physiological state of microalgae. ${ }^{17,19}$ Most reports studied the effects of nitrate on the growth and photosynthesis of $D$. salina, however, the study on the chlorophyll fluorescence and growth kinetics under different phosphate concentrations with nitrogen limitation are few. ${ }^{7,20}$ This research was aimed to provide a scientific guidance for the future commercial cultivation of this $D$. salina strain by studying the growth habits under different phosphate concentrations.

\section{Materials and Methods}

\section{Algae strain and cultivation conditions}

D. salina KU XI was isolated from saline soils in Buriram, Thailand. It was also known as Dunaliella salina BuriRam KU 01 with 18S rDNA accession number of JN052202 in National Center for Biotechnology Information. ${ }^{21}$ The strain was cultured at $30^{\circ} \mathrm{C}$ in $\mathrm{f} / 2$ medium in a column photobioreactor with a working volume of $250 \mathrm{~mL}$. The salinity ( $\mathrm{NaCl}$ concentration) was $2.5 \mathrm{M}$. The initial $\mathrm{pH}$ was adjusted at 7.5 by diluted $\mathrm{HCl}$ and the culture was inoculated $5 \%$ algae starter with the cell density around $7 \times 10^{6} \mathrm{~mL}^{-1}$. Bioreactors were aerated with compressed air containing $5 \% \mathrm{CO}_{2}(\mathrm{v} / \mathrm{v})$ at approx. $0.01 \mathrm{vvm}$ (volume of air per volume of medium per minute) and irradiated continuously from two sides with cool white fluorescence lamps giving $54 \mu \mathrm{mol} \mathrm{m}{ }^{-2} \mathrm{~s}^{-1} .^{15}$ $\mathrm{NaH}_{2} \mathrm{PO}_{4}$ concentration was modified to $0,1 / 16,1 / 8,1 / 4,1 / 3,1 / 2,1 / 1.5$, $1 / 1.2,1,2,3,4$ and 8 times the original $\mathrm{NaH}_{2} \mathrm{PO}_{4}$ concentration (36.3 $\mu \mathrm{M})$ in $\mathrm{f} / 2$ medium. The details of phosphate concentrations were shown in Table $1 . \mathrm{NaNO}_{3}$ was $1.2 \mathrm{mM}$ and other chemicals in $\mathrm{f} / 2$ medium were maintained the original concentration. Each treatment was set three repetitions. Algae were cultured 15 days.

\section{Cell density and dry biomass weight}

Cell density was checked by daily counting in a haematocytometer and the raw data was processed with the method of sigmoid curve fitting by the software of Table Curve 2D v5.01 for calculating the specific growth rate $(\mu) .50 \mathrm{~mL}$ sample was centrifuged at $3000 \mathrm{~g}$ for $5 \mathrm{~min}$ and washed by distilled water, the pellets were dried in oven at $60^{\circ} \mathrm{C}$ for two days. Finally the dry biomass weight and specific growth rate were calculated by following equations: DW=SW/ $\mathrm{V}_{\mathrm{t}} ; \mu=\ln \left(\mathrm{N}_{2} / \mathrm{N}_{1}\right) /\left(\mathrm{t}_{2}-\mathrm{t}_{1}\right)$; Where DW was dry biomass weight ( $\left.\mathrm{g} \mathrm{L}^{-1}\right)$; SW was sample dry weight $(\mathrm{g}) ; \mathrm{V}_{\mathrm{t}}$ was sample volume (L); $\mu$ was specific growth rate (day ${ }^{-1}$ ); $\mathrm{N}_{2}$ or $\mathrm{N}_{1}$ was cell density at different day of $t_{2}$ and $t_{1}$ in exponential growth stage.

Pigments extraction and measurement

Five $\mathrm{mL}$ sample was centrifuged at $3000 \mathrm{~g}$ for $5 \mathrm{~min}$. The pellets were dissolved into $1 \mathrm{~mL}$ cold methanol with $0.1 \%$ (w/v) butylated hydroxytoluene and sonicated for $10 \mathrm{~min}$. The pellets were extracted by acetone (90\%) for $30 \mathrm{~min}$. The optical densities of supernatants were examined by ultraviolet spectrophotometer. All procedures were conducted under dim laboratory light to prevent pigment photo-oxidation. ${ }^{6}$ The chlorophyll contents were calculated from the equation: $\mathrm{Chl}=\left(8.02 \times 0 \mathrm{D}_{645}+\right.$ $\left.20.21 \times 0 \mathrm{D}_{663}\right) \times \mathrm{V}_{\mathrm{e}} \mathrm{N}_{\mathrm{t}}$. Where $\mathrm{Chl}$ is the chlorophyll content $\left(\mathrm{mg} \mathrm{L}^{-1}\right) ; \mathrm{OD}_{645}$ and $\mathrm{OD}_{663}$ are the absorbance at 645 and $663 \mathrm{~nm} ; \mathrm{V}_{\mathrm{e}}$ and $\mathrm{V}_{\mathrm{t}}$ was volume of extract and culture sample respectively (mL). ${ }^{15,22}$ The beta-carotene content was found from the standard curve, which was determined by the known standard beta-carotene sample weight and the value of optical density at $450 \mathrm{~nm}$. The regression equation used was $y=0.9971 x+2.9832$ where $y$ is beta-carotene content $\left(\mathrm{mg} \mathrm{L}^{-1}\right)$ and $x$ is the $0 \mathrm{D}_{450}$ value.

\section{Chlorophyll content and chlorophyll fluorescence}

Chlorophyll fluorescence was measured by Water-PAM Chlorophyll Fluorometer (Waltz, Effeltrich, Germany). Two $\mathrm{mL}$ fresh algae samples was placed in darkness for $20 \mathrm{~min}$ and checked the basal fluorescence $\mathrm{F}_{0}$ with the measuring light $\left(0.01 \mu \mathrm{mol} \mathrm{m} \mathrm{m}^{-2} \mathrm{~s}^{1}\right)$. The maximum fluorescence $F_{m}$ was measured after the sample excited by high intensity of saturation pulse $\left(4000 \mu \mathrm{mol} \mathrm{m}-{ }^{2} \mathrm{~s}^{-1}\right)$ for $0.8 \mathrm{~s}$. The maximum quantum yield of PS II photochemistry $F_{v} / F_{m}=\left(F_{m}-F_{0}\right) / F_{m}$. The instant fluorescence value was positive related with the chlorophyll content in a certain range ${ }^{17}$ therefore, the chlorophyll content could be obtained by the calibrated curve of fluorescence value with chlorophyll content. In order to reduce errors, the relative chlorophyll content was used in this study, namely the value of daily measured chlorophyll content from the Chlorophyll Fluorometer divided by the beginning chlorophyll content.

\section{Data process}

All data were processed by the software of Microsoft Excel 2010, Origin8.0Pro and TableCurve 2D v 5.01, analyzed by SPSS 16.0 with the method of ANOVA and multiple comparisons (Duncan's New Multiple Range Test).

\section{Results}

\section{Cell growth under different phosphate concentrations}

ANOVA and multiple comparison results showed that phosphorus could significantly affect the cell growth $(\mathrm{F}=54, \mathrm{P}<0.01)$. Cell density, biomass and the specific growth rate were significantly restrained when $\mathrm{NaH}_{2} \mathrm{PO}_{4}$ concentration below $12.1 \mu \mathrm{M}$ and rapidly improved following the increase of $\mathrm{NaH}_{2} \mathrm{PO}_{4}$ concentration (Figure 1 and Table 1). However, the final biomass was not significantly different when $\mathrm{NaH}_{2} \mathrm{PO}_{4}$ concentration above $72.6 \mu \mathrm{M}$ (Table 1). It implied that the growth would be restrained by nitrate when phosphate concentration above $72.6 \mu \mathrm{M}$.

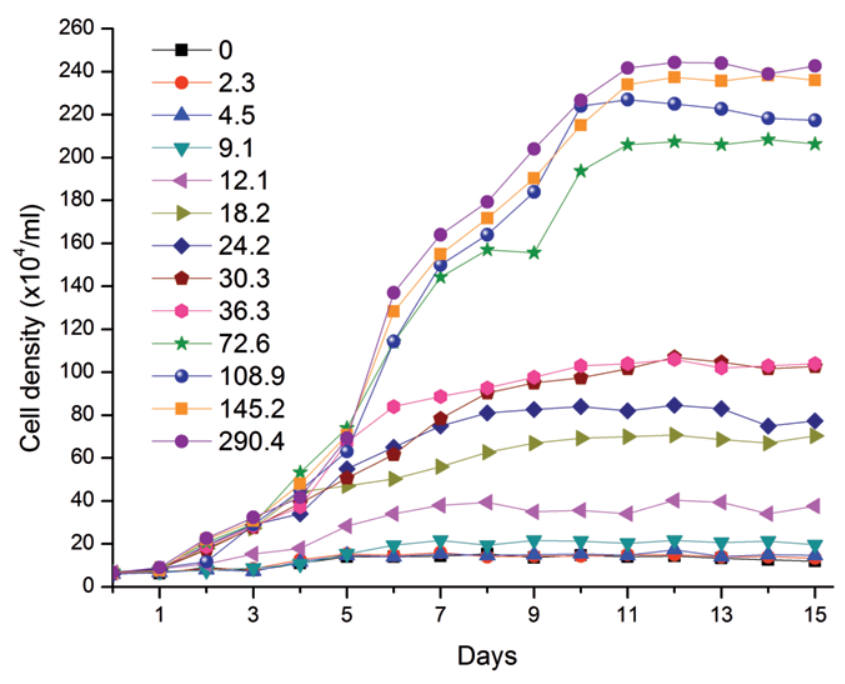

Figure 1. Cell growth of Dunaliella salina KU XI under different $\mathrm{NaH}_{2} \mathrm{PO}_{4}$ concentrations. 


\section{Effects of $\mathrm{NaH}_{2} \mathrm{PO}_{4}$ concentrations on the chlorophyll fluorescence}

The maximum quantum yield of PS II photochemistry was significantly affected by phosphorus $(\mathrm{F}=53, \mathrm{P}<0.01) . \mathrm{F}_{\sqrt{ }} / \mathrm{F}_{\mathrm{m}}$ values under different $\mathrm{NaH}_{2} \mathrm{PO}_{4}$ concentrations were all decreased following the culturing time and decreased slowly in the high phosphate concentration (Figure 2). It suggested that the nutrient could be supplied to the medium in the late growth stage for maintaining the continuous high growth conditions. $\mathrm{F}, \mathrm{F}_{\mathrm{m}}$ values dramatically decreased after the second day when $\mathrm{NaH}_{2} \mathrm{PO}_{4}$ concentration below $12.1 \mu \mathrm{M}$ (Figure 2). Above results were highly consistent with the algae growth conditions under different $\mathrm{NaH}_{2} \mathrm{PO}_{4}$ concentrations. It indicated that the parameter of the maximum quantum yield of PS II photochemistry $\left(\mathrm{F}_{\mathrm{V}} / \mathrm{F}_{\mathrm{m}}\right)$ could reflect the algae growth conditions.

\section{Effects of $\mathrm{NaH}_{2} \mathrm{PO}_{4}$ concentrations on the chlorophyll and beta-carotene accumulation}

The conditions of chlorophyll accumulation were consistent with the cell growth (Figures 1 and 3). The chlorophyll rapidly increased to the maximum at the seventh day and gradually decreased following the cultivation time (Figure 3). However, the total beta-carotene content was rapidly increased after seven days and the maximum beta-carotene content appeared in the highest $\mathrm{NaH}_{2} \mathrm{PO}_{4}$ concentration. To the contrary, the highest carotenoids/chlorophyll ratio was shown when phosphate concentration below $12.1 \mu \mathrm{M}$ (Table 1). Due to the high cell density, high content of beta-carotene was accumulated although the low content per cell (Table 1). Hence properly improving phosphate concentration was favored for improving the total beta-carotene yield.

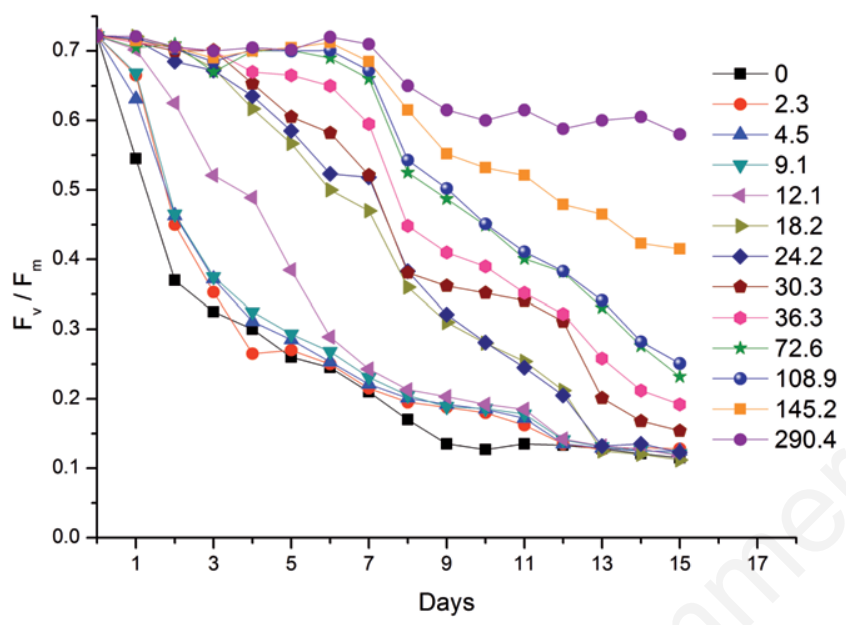

Figure 2. The variation of $\mathrm{F}_{\mathrm{v}} / \mathrm{F}_{\mathrm{m}}$ values of Dunaliella salina $\mathrm{KU}$ $\mathrm{XI}$ under different $\mathrm{NaH}_{2} \mathrm{PO}_{4}$ concentrations.

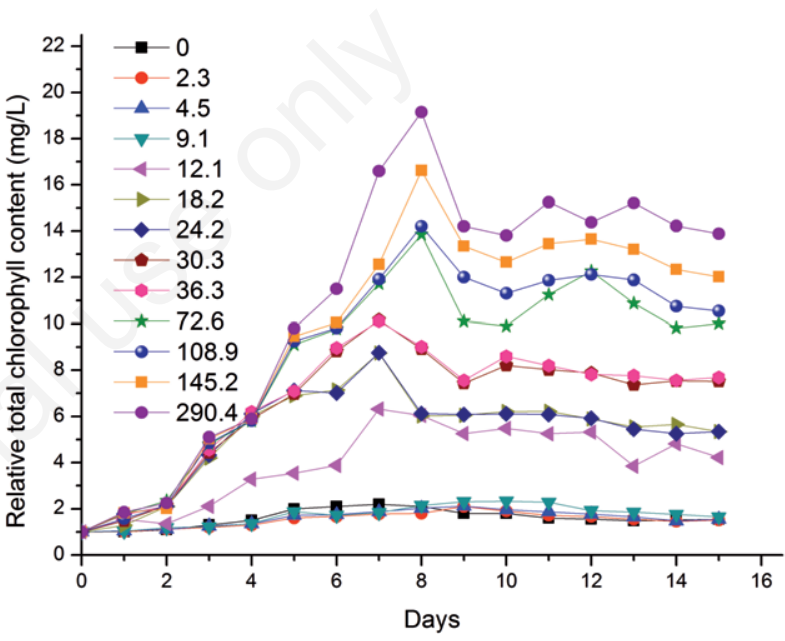

Figure 3. The relative total chlorophyll content of Dunaliella sali$n a$ KU XI under different $\mathrm{NaH}_{2} \mathrm{PO}_{4}$ concentrations.

Table 1. Biomass and beta-carotene production of Dunaliella salina KU XI under different $\mathrm{NaH}_{2} \mathrm{PO}_{4}$ concentrations.

\begin{tabular}{|c|c|c|c|c|c|}
\hline $\begin{array}{l}\mathrm{NaH}_{2} \mathrm{PO}_{4} \\
\text { content }(\mu \mathrm{M})\end{array}$ & $\begin{array}{l}\text { Specific growth } \\
\text { rate }\left(\mu, \text { day }^{-1}\right)\end{array}$ & $\begin{array}{l}\text { Dry biomass } \\
\text { weight (DW, g L-1) }\end{array}$ & $\begin{array}{c}\text { Beta-carotene } \\
\text { content per volume } \\
\left(\mathrm{mg} \mathrm{L}^{-1}\right)\end{array}$ & $\begin{array}{l}\text { Beta-carotene } \\
\text { content in cell (pg) }\end{array}$ & $\begin{array}{c}\text { Ratio of } \\
\text { carotene/chlorophyll }\end{array}$ \\
\hline 0 & $0.13 \pm 0.01^{\mathrm{a}}$ & $0.01 \pm 0.01^{\mathrm{a}}$ & $0.91 \pm 0.09^{\mathrm{a}}$ & $8.21 \pm 0.21^{\mathrm{d}}$ & $0.62 \pm 0.15^{c}$ \\
\hline 2.3 & $0.14 \pm 0.01^{\mathrm{a}}$ & $0.01 \pm 0.01^{\mathrm{a}}$ & $1.12 \pm 0.13^{\mathrm{a}}$ & $8.41 \pm 0.26^{\mathrm{d}}$ & $0.61 \pm 0.18^{b c}$ \\
\hline 4.5 & $0.16 \pm 0.01^{\mathrm{a}}$ & $0.02 \pm 0.02^{\mathrm{a}}$ & $1.15 \pm 0.1^{\mathrm{a}}$ & $7.61 \pm 0.18^{c}$ & $0.55 \pm 0.12^{\mathrm{abc}}$ \\
\hline 9.1 & $0.33 \pm 0.01^{\mathrm{b}}$ & $0.02 \pm 0.02^{\mathrm{a}}$ & $1.21 \pm 0.15^{\mathrm{a}}$ & $6.21 \pm 0.21^{\mathrm{a}}$ & $0.48 \pm 0.13^{\mathrm{abc}}$ \\
\hline 12.1 & $0.40 \pm 0.02^{c}$ & $0.03 \pm 0.02^{\mathrm{a}}$ & $2.36 \pm 0.24^{\mathrm{ab}}$ & $6.31 \pm 0.17^{a}$ & $0.33 \pm 0.13^{\mathrm{a}}$ \\
\hline 18.2 & $0.45 \pm 0.04^{\mathrm{d}}$ & $0.07 \pm 0.02^{\mathrm{ab}}$ & $4.36 \pm 0.38^{b c}$ & $6.34 \pm 0.15^{\mathrm{a}}$ & $0.32 \pm 0.15^{\mathrm{a}}$ \\
\hline 24.2 & $0.46 \pm 0.02^{\mathrm{d}}$ & $0.07 \pm 0.03^{\mathrm{ab}}$ & $4.93 \pm 0.35^{\mathrm{cd}}$ & $6.41 \pm 0.13^{\mathrm{a}}$ & $0.33 \pm 0.16^{\mathrm{a}}$ \\
\hline 30.3 & $0.45 \pm 0.03^{\mathrm{d}}$ & $0.1 \pm 0.03^{b}$ & $6.43 \pm 0.68^{\mathrm{cd}}$ & $6.26 \pm 0.18^{a}$ & $0.33 \pm 0.11^{\mathrm{a}}$ \\
\hline 36.3 & $0.49 \pm 0.02^{\mathrm{e}}$ & $0.11 \pm 0.01^{b}$ & $6.6 \pm 0.72^{\mathrm{d}}$ & $6.37 \pm 0.19^{\mathrm{a}}$ & $0.34 \pm 0.13^{\mathrm{a}}$ \\
\hline 72.6 & $0.57 \pm 0.02^{\mathrm{g}}$ & $0.2 \pm 0.04^{c}$ & $14.9 \pm 1.61^{\mathrm{e}}$ & $7.21 \pm 0.21^{b}$ & $0.35 \pm 0.09^{a}$ \\
\hline 108.9 & $0.55 \pm 0.03 \mathrm{fg}$ & $0.21 \pm 0.05^{c}$ & $16.1 \pm 2.02^{\mathrm{ef}}$ & $7.41 \pm 0.25 \mathrm{bc}$ & $0.37 \pm 0.12^{\mathrm{ab}}$ \\
\hline 145.2 & $0.57 \pm 0.03^{g}$ & $0.23 \pm 0.05^{c}$ & $17.4 \pm 2.27^{\mathrm{f}}$ & $7.41 \pm 0.26^{\mathrm{bc}}$ & $0.36 \pm 0.1^{\mathrm{ab}}$ \\
\hline 290.4 & $0.53 \pm 0.02^{f}$ & $0.24 \pm 0.04^{c}$ & $17.4 \pm 2.4^{\mathrm{f}}$ & $7.21 \pm 0.27^{b}$ & $0.39_{ \pm} 0.13^{\mathrm{ab}}$ \\
\hline
\end{tabular}

DW, dry weight. The strain was cultured in $\mathrm{f} / 2$ medium with $0.1 \mathrm{~g} \mathrm{~L}^{-1} \mathrm{NaNO}_{3}$. All data were collected on the $15^{\text {th }}$ day and presented by the average value \pm standard deviation. Duncan's New Multiple Range Test was used to compare the mean differences and the different alphabet letters shown in the same column denote significant difference effects between each other $(\mathrm{P}<0.05)$. 


\section{Growth kinetics of Dunaliella salina KU XI based on different phosphate concentrations}

The growth rate of microalgae was dependent solely on the concentration of a particular limiting nutrient. Thus, the Monod model was described as:

$\mu=\mathrm{f}(\mathrm{s})=\mu_{\mathrm{m}}\left[\mathrm{S} /\left(\mathrm{K}_{\mathrm{s}}+\mathrm{S}\right)\right]$

in which $\mu$ was specific growth rate, day ${ }^{1} ; \mu_{\mathrm{m}}$ was maximum specific growth rate, day ${ }^{1} ; \mathrm{S}$ was limiting nutrient concentration, $\mathrm{mg} \mathrm{L}^{-1} ; \mathrm{K}_{\mathrm{s}}$ was half saturation coefficient. ${ }^{7,23}$

Lineweaver-Burk plot was applied to the Eq.1, $1 / \mu$ and $1 / \mathrm{S}$ were dependent variable and independent variable respectively, and a linear equation was obtained, namely $1 / \mu=\left(\mathrm{K}_{s} / \mu_{\mathrm{m}}\right) \cdot(1 / \mathrm{S})+1 / \mu_{\mathrm{m}}$. Thus, the slope from this equation was $\mathrm{K}_{s} / \mu_{\mathrm{m}}$; intercept in y axis and $\mathrm{x}$ axis was $1 / \mu_{\mathrm{m}}$ and $-1 / \mathrm{K}_{\mathrm{s}}$ respectively. In this study, $\mathrm{S}$ was phosphate concentration, the linear equation was obtained, namely $\mathrm{y}=14.085 \mathrm{x}+1.6902$, $\mathrm{R}^{2}=0.93$, and the slop in $\mathrm{x}$ axis was -0.12 , hence, $\mathrm{K}_{\mathrm{s}}=8.33$. Therefore, eq. 1 was changed as:

$\mu=\mu_{\mathrm{m}}[\mathrm{S} /(8.33+\mathrm{S})]$

The maximum growth rate as defined by the Monod relationship was still a function of other environmental variables. When light intensity was held constant, it is possible to describe the maximum growth rate solely as a function of temperature by applying the Arrhenius equation: ${ }^{23}$

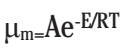

in which A was constant; E was activation energy, cal mol $^{-1}$; $\mathrm{R}$ was universal gas constant, cal $\mathrm{K}^{-1} \mathrm{~mol}^{-1}$; and T was temperature, Kelvin scale, $\mathrm{K}$. According to the growth rate of KU XI at different temperature, ${ }^{15,16,24}$ an equation could be obtained: $\mu_{\mathrm{m}}=1.26 \times 10^{6} \mathrm{e}^{-4419 / T}$. Thus, eq. 4 could be as follows:

$\mu=1.26 \times 10^{6} \mathrm{e}^{-4419 / \mathrm{T}}[\mathrm{S} /(8.33+\mathrm{S})]$

Eq. 4 was the model incorporates the combined effects of temperature and phosphate concentration on the growth of $D$. salina KU XI. The average relative standard deviation of $\mu$ between the value calculated from the Eq. 4 and the measured value was $5.44 \%$ and it has higher fitting accuracy for this $D$. salina strain.

\section{Discussion}

Present studies showed that light-saturated photosynthesis rate was decreased under phosphorus limitation. Concentration of phosphorus in microalgae was dropped resulted photophosphorylation, ATP synthesis, Calvin cycle efficiency and regenerative cycle of $\mathrm{NADP}^{+}$and NADPH being retard or restrained. While $\mathrm{NADP}^{+}$was the final electron acceptor in the photosynthetic chain and it's inevitable to cause PS II function declined that resulted the efficiency and quantum yield of PS II photochemistry decreased..$^{9,18,25}$

The value of $F_{v} / F_{m}$ was rapidly dropped after two days when the phosphate concentration decreased and this trend was significant when $\mathrm{NaH}_{2} \mathrm{PO}_{4}$ concentration was below $12.1 \mu \mathrm{M}$. This could be explained that microalgae could accumulate $\mathrm{PO}_{4}{ }^{3-}$ in cytoplasm to form polyphosphoric particles which could be functioned as a store to provide necessary phosphorus to maintain the physiology metabolism. ${ }^{26}$ Hence, it did not show significant growth restriction under low phosphate concentration at the beginning days. Obviously, high phosphate concentration could retard the decrease of $F_{V} / F_{m}$ value (Figure 2). In addition, by comparing our previous researches, $, 5,24,27$ the cell densities of KU XI was up to $8 \times 10^{4} \mathrm{~mL}^{-1}$ which was far higher than the result in this study when nitrate above $0.5 \mathrm{~g} \mathrm{~L}^{-1}$. Thus the transition of restrained algae growth was changed from phosphorus to nitrogen when $\mathrm{NaH}_{2} \mathrm{PO}_{4}$ concentration was lower $12.1 \mu \mathrm{M}$ or higher $72.6 \mu \mathrm{M}$ (Figure 1). This results was in agreement with conclusion that no multiplicative or additive effect between nitrogen and phosphorus limitation of microalgae growth. ${ }^{7}$

Phosphorus is important component of nucleic acid and necessary element for cell metabolic and energy conversion. ${ }^{11,28}$ Efficiency of Calvin cycle of photosynthesis in microalgae was decreased under low phosphorus, which retarded or ceased chlorophyll synthesis and cell division. ${ }^{9,25}$ Studies reported that the alga was in the conditions of absent phosphorus if $\mathrm{KH}_{2} \mathrm{PO}_{4}$ below $1.5 \mu \mathrm{M}$ and also the growth was restrained when $\mathrm{KH}_{2} \mathrm{PO}_{4}$ was above $600 \mu \mathrm{M}$. The suitable concentration of $\mathrm{KH}_{2} \mathrm{PO}_{4}$ for algae growth was 30-120 $\mu \mathrm{M} .{ }^{7,25}$ In this study, the growth of $D$. saline $\mathrm{KU} \mathrm{XI}$ was generally consistent with above reports. The cell density was significantly low when $\mathrm{NaH}_{2} \mathrm{PO}_{4}$ was below $12.1 \mu \mathrm{M}$ and rapidly increased when the concentration was above $72.6 \mu \mathrm{M}$ (Figure 1). Moreover, the maximum cell densities were not significantly different after 10 days when phosphorus was above $72.6 \mu \mathrm{M}$. This could be related with the high phosphorus concentration in this study was either lower than the maximum P-limited concentration or insensitive for algae growth. ${ }^{7,14}$ However, high phosphorus concentration could limit the growth of Chaetoceros gracilis. ${ }^{17,26}$

Nitrogen and phosphorus in the sea were ranged at 0.1-50 $\mu \mathrm{M}$ and 0.1-2 $\mu \mathrm{M}$, far lower than the optimal concentration for the planktonic microorganism. Some studies reported that $5 \mathrm{mM}$ or $10 \mathrm{mM}$ nitrate was suited for biomass production of $D$. salina ${ }^{16,24} \mathrm{D}$. salina could produce beta-carotene and lipid under nutrition limitation. ${ }^{1}$ Therefore, the nitrate concentration was often limited below $3 \mathrm{mM}$ in the actual algal cultivation. ${ }^{29}$ In this study, nitrate concentration was $1.2 \mathrm{mM}$, which was reasonable for the study of the algae growth.

The growth kinetics (eq. 4) well described the specific growth rate and predicted the growth conditions of $D$. salina XI. However, this equation strengthened the specific growth rate under different phosphate concentrations. Hence, the growth kinetics of $D$. salina XI could not predict the final or maximum biomass. The maximum biomass depends on the cultivation conditions. ${ }^{1,6}$ Obviously, the algae strains with high specific growth rate could rapidly reach the maximum cell density in short time. Considering the requirements of actual biomass or beta-carotene production, we suggested the phosphate should be higher $72.6 \mu \mathrm{M}$ although the specific growth rate was also high when phosphate above $18.2 \mu \mathrm{M}$.

Chlorophyll is important pigment for photosynthesis in phytoplankton. Chlorophylls synthesis was declined under nutrient limitation thereby caused the decrease of photosynthesis and biomass accumulation. The variation of chlorophyll content could indicate the photosynthesis and growth conditions of microalgae. ${ }^{19}$ In this study, the chlorophyll content in high phosphate concentration was significantly higher than that in low phosphate concentration and a positive correlative relation was shown between the cell density and chlorophyll. Betacarotene content in a cell was gradually increased when phosphate concentration decreased (Table 1). However, the highest beta-carotene content per volume appeared in the highest phosphorus concentration. This result was related with the high cell densities leading to high volumetric carotenoids accumulation. Moreover, chlorophyll content in this research was checked by the chlorophyll fluorometer. This method possesses merits of requiring rapid, few samples and freeing the cell from injury. However, this method should be calibrated by the measured value from the traditional ways (UV spectrophotometry, HPLC method, etc.). In this study, the relative chlorophyll content was adapted due to that the relative content could express the effects of environmental factors on the algae growth and avoids the calibration errors. 


\section{Conclusions}

Phosphorus could significantly affect algae growth and pigments accumulation. Increasing $\mathrm{NaH}_{2} \mathrm{PO}_{4}$ concentration improved the biomass, the total chlorophyll and beta-carotene content of $D$. salina KU $\mathrm{XI}$, and retarded the decrease of the maximum quantum yield of PS II photochemistry $\left(\mathrm{F}_{\sqrt{\mathrm{m}}} / \mathrm{F}_{\mathrm{m}}\right)$. The optimal phosphate concentration for the growth of $D$. salina KU XI was above $72.6 \mu \mathrm{M}$. The algae growth was restrained by phosphate or nitrate when $\mathrm{NaH}_{2} \mathrm{PO}_{4}$ below $12.1 \mu \mathrm{M}$ or above $72.6 \mu \mathrm{M}$. The growth kinetics of $D$. salina $\mathrm{KU}$ XI was established. It could simulate the algae growth rate under different phosphate concentrations and temperatures.

\section{References}

1. Hosseini Tafreshi A, Shariati M. Dunaliella biotechnology: methods and applications. J Appl Microbiol 2009;107:14-35.

2. Borowitzka LJ. Development of western biotechnology's algal carotene plant. Bioresour Technol 1991;38:251-2.

3. Borowitzka MA. Dunaliella: biology, production, and markets. New York: John Wiley \& Sons, Ltd; 2013.

4. Prieto A, Pedro Cañavate J, García-González M. Assessment of carotenoid production by Dunaliella salina in different culture systems and operation regimes. J Biotechnol 2011;151:180-5.

5. Borowitzka MA. Commercial production of microalgae: ponds, tanks, tubes and fermenters. J Biotechnol 1999;70:313-21.

6. Jiang JG, Zhu YH. Preliminary and comparative studies on the cultivations of Dunaliella salina between outdoors and in the photobioreactor. J Food Process Eng 2010;33:104-14.

7. Rhee GY. Effects of N:P atomic ratios and nitrate limitation on algal growth, cell composition, and nitrate uptake 1. Limnol Oceanogr 1978;23:10-25.

8. Hill R. Chlorophyll. In: Marcel F, Elmer HS, eds. Comprehensive biochemistry. Amsterdam: Elsevier; 2014. p. 73-97.

9. Jacob J, Lawlor D. In vivo photosynthetic electron transport does not limit photosynthetic capacity in phosphate deficient sunflower and maize leaves. Plant Cell Environ 1993;16:785-95.

10. Lv H, Cui X, Wahid F, et al. Analysis of the physiological and molecular responses of dunaliella salina to macronutrient deprivation. PLoS One 2016;11:e0152226.

11. Masojídek J, Torzillo G, Koblížek M. Photosynthesis in microalgae. New York: John Wiley \& Sons, Ltd; 2013.

12. Lamers PP, van de Laak CCW, Kaasenbrood PS, et al. Carotenoid and fatty acid metabolism in light-stressed Dunaliella salina. Biotechnol Bioeng 2010;106:638-48.

13. Li Y, Han D, Yoon K, et al. Molecular and cellular mechanisms for lipid synthesis and accumulation in microalgae: biotechnological implications. New York: John Wiley \& Sons, Ltd; 2013.

14. Rhee G-Y, Gotham IJ. Optimum N:P ratios and coexistence of planktonic algae 1. J Phycol 1980;16:486-9.

15. Wu Z, Duangmanee P, Zhao P, et al. The effects of light, temperature, and nutrition on growth and pigment accumulation of three Dunaliella salina strains isolated from saline soil. Jundishapur J Microbiol 2016;9:e26732.

16. Wu Z, Akter R, Arirob W, et al. Effects of light intensity and the remaining nitrate concentration on the beta-carotene accumulation of a wild Dunaliella salina strain isolated from the saline soil. Microbiol Res 2015;2015:6.

17. Rohá ek K, Soukupová J, Barták M. Chlorophyll fluorescence: a wonderful tool to study plant physiology and plant stress. Plant Cell Compartments 2008;2008:41-104.

18. Parkhill JP, Maillet G, Cullen JJ. Fluorescence based maximal quantum yield for PSII as a diagnostic of nutrient stress. J Phycol 2001;37:517-29.

19. Papageorgiou GC. Chlorophyll a fluorescence: a signature of photosynthesis. New York: Springer Science \& Business Media; 2007.

20. Yin C, Liang Y, Feng L, Cao C. Effects of different nitrogen concentration on the chlorophyll fluorescence and growth of Dunaliella salina and Chaetoceros gracilis. Trans Oceanol Limnol 2007;1:10110.

21. Sathasivam R, Kermanee P, Roytrakul S, Juntawong N. Isolation and molecular identification of -carotene producing strains of Dunaliella salina and Dunaliella bardawil from salt soil samples by using species-specific primers and internal transcribed spacer (ITS) primers. Afr J Biotechnol 2012;11:16677-87.

22. Abu-Rezq TS, Al-Hooti S, Jacob D, et al. Induction and extraction of -carotene from the locally isolated Dunaliella salina. Algal Biomass Ut 2010;1:58-83.

23. Goldman JC, Carpenter EJ. A kinetic approach to the effect of temperature on algal growth. Limnol Oceanogr 1974;19:756-66.

24. Sathasivam R, Juntawong N. Modified medium for enhanced growth of Dunaliella strains. Int J Curr Sci 2013;5:67-73.

25. Lippemeier S, Frampton DM, Blackburn SI, et al. Influence of phosphorus limitation on toxicity and photosynthesis of Alexandrium minutum (Dinophyceae) monitored by in-line detection of variable chlorophyll fluorescence 1. J Phycol 2003;39:320-31.

26. Tilman D. Resource competition and community structure. Princeton: Princeton University Press; 1982.

27. Wu Z, Akter R, Arirob W, et al. Effects of light intensity and the remaining nitrate concentration on the beta-carotene accumulation of a wild Dunaliella salina strain isolated from the saline soil. Microb Res 2015;6:6-10.

28. Ye Z-W, Jiang J-G, Wu G-H. Biosynthesis and regulation of carotenoids in Dunaliella: progresses and prospects. Biotechnol Adv 2008;26:352-60.

29. Avron M, Ben-Amotz A. Production of glycerol, carotenes and algae meal. Google Patent. Mountain View: Google; 1980. 